\title{
Determination Method for Steroid $5 \alpha$-Reductase Activity Using Liquid Chromatography/Atmospheric Pressure Chemical Ionization-Mass Spectrometry
}

\author{
Kuniko Mitamura, Chie Ogasawara, Asami Shiozawa, Erika Terayama, and \\ Kazutake SHIMADA ${ }^{\dagger}$
}

Division of Pharmaceutical Sciences, Graduate School of Natural Science and Technology, Kanazawa University, Kakuma-machi, Kanazawa 920-1192, Japan

\begin{abstract}
A determination method for steroid $5 \alpha$-reductase activity using liquid chromatography/atmospheric pressure chemical ionization-mass spectrometry (LC/APCI-MS) in the positive-ion mode has been developed. The rat prostatic enzyme source was used and the enzymatically formed $5 \alpha$-dihydrotestosterone and $5 \alpha$-androstane- $3 \alpha, 17 \beta$-diol were determined by LC/APCI-MS using absolute calibration curve method. The sum of the formed products was used as a measurement of the enzyme activity. This method was applied to kinetic study of this enzyme and inhibitory experiments using Finasteride ${ }^{\circledR}$ as a model inhibitor.
\end{abstract}

(Received July 7, 2005; Accepted August 9, 2005)

\section{Introduction}

Testosterone $(\mathrm{T})$ is metabolized to $5 \alpha$-dihydrotestosterone ( $5 \alpha$ DHT), which is produced by the catalysis of steroid $5 \alpha-$ reductase ( $5 \alpha$-Red), and other metabolites in humans (Fig. 1). It is well known that these androgens, primarily $5 \alpha$-DHT, is responsible for the development of benign prostate hyperplasia $(\mathrm{BPH})$ or prostate cancer. In humans, which spontaneously develop BPH with age, two isoenzymes $(5 \alpha \mathrm{R} 1$ and $5 \alpha \mathrm{R} 2)$ of $5 \alpha$-Red have been identified and are over-expressed in BPH. ${ }^{2}$ It is important to develop the $5 \alpha$-Red inhibitor, such as Finasteride $^{\circledR}$, for BPH and prostate cancer. ${ }^{3}$ Although several determination methods for the $5 \alpha$-Red activity have been reported, these methods used radiolabeled $\mathrm{T}$ as a substrate and the consumed radiolabeled T or formed radiolabeled-5 $\alpha$-DHT and $-5 \alpha$-androstane- $3 \alpha, 17 \beta$-diol $(3 \alpha, 5 \alpha$-diol $)$ was measured using HPLC $^{4}$ or TLC $^{5}$ with a radioactivity detector. The treatment of the radiolabeled compound is not convenient for routine analysis and the determination method for the $5 \alpha$-Red activity without using a radiolabeled compound is required for the study of the enzyme properties or development of a $5 \alpha$-Red inhibitor.

In this study, we developed a determination method for the $5 \alpha$-Red activity using liquid chromatography/atmospheric pressure chemical ionization-mass spectrometry (LC/APCIMS). The rat prostatic enzyme source was used, and the enzymatically formed $5 \alpha$-DHT and $3 \alpha, 5 \alpha$-diol were determined by LC/APCI-MS using absolute calibration curve method. The sum of the formed products was used as a measurement of the enzyme activity. This method was applied to kinetic study of this enzyme and inhibitory experiment using Finasteride ${ }^{\circledR}$ as a model inhibitor.

\footnotetext{
† To whom correspondence should be addressed

E-mail: shimada@p.kanazawa-u.ac.jp
}

\section{Experimental}

\section{$L C / A P C I-M S$}

LC/APCI-MS was performed using a LCQ (ThermoElectron, San Jose, CA, USA) liquid chromatograph/ion trap-mass spectrometer connected to a PU-980 (Jasco, Tokyo, Japan) chromatograph, and the APCI (positive-ion mode) was employed. A Chromolith Performance RP-18e $(100 \times 4.6 \mathrm{~mm}$ i.d.; Merck, Darmstadt, Germany) was used at a flow rate of 1.0 $\mathrm{ml} / \mathrm{min}$ and $40^{\circ} \mathrm{C}$. The ionization conditions were as follows. Ion source current, $5 \mu \mathrm{A}$; vaporizer temperature, $550^{\circ} \mathrm{C}$; capillary temperature, $230^{\circ} \mathrm{C}$; capillary voltage, $20 \mathrm{~V}$; sheath gas flow rate, 80 units; tube lens offset voltage, $20 \mathrm{~V}$. All steroids were analyzed in the selected ion monitoring (SIM) mode.

\section{Materials}

T, $5 \alpha$-DHT and androsterone were purchased from Tokyo

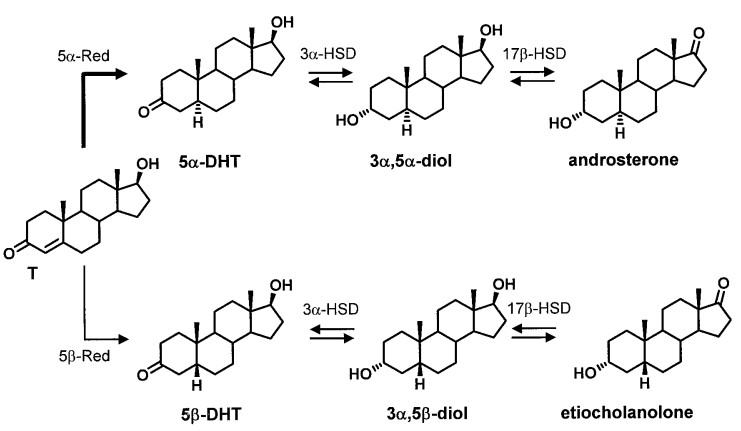

Fig. 1 Metabolic pathway of T. $5 \beta$-Red: $5 \beta$-reductase, $3 \alpha$-HSD: $3 \alpha$-hydroxysteroid dehydrogenase, $17 \beta$-HSD: $17 \beta$-hydroxysteroid dehydrogenase. 
Kasei Kogyo (Tokyo), and $5 \beta$-dihydrotestosterone ( $5 \beta$-DHT) $3 \alpha, 5 \alpha$-diol, $\quad 5 \beta$-androstane- $3 \alpha, 17 \beta$-diol $\quad(3 \alpha, 5 \beta$-diol $) \quad$ and etiocholanolone were obtained from Steraloids (Newport, RI, USA). Finasteride ${ }^{\circledR}$ and 16,16,17-trideuterated $5 \alpha$-DHT $\left\{\left[{ }^{2} \mathrm{H}_{3}\right]-\right.$ $5 \alpha$-DHT $\}$ were donated from Teikoku Hormone Medical Research (Kawasaki, Japan). $\beta$-NADPH (NADPH) and dithiothreitol (DTT) were obtained from Wako Pure Chemical (Osaka, Japan) and Nacalai Tesque (Kyoto, Japan), respectively. Oasis HLB cartridges $(60 \mathrm{mg}, 3 \mathrm{ml})$ were purchased from Waters (Milford, MA, USA), and successively conditioned with $\mathrm{MeOH}(2 \mathrm{ml})$ and $\mathrm{H}_{2} \mathrm{O}(2 \mathrm{ml})$ prior to use. All other chemicals used were of analytical grade.

\section{Preparation of enzyme source}

The enzyme source was prepared by modification of the method described by Span et al. ${ }^{6}$ Wistar strain male rats (7 weeks old; Japan S.L.C., Hamamatsu, Japan) were decapitated and the whole prostate was removed. The prostate $(\mathrm{ca} .0 .3 \mathrm{~g})$ was homogenized in $1 \mathrm{ml}$ of $40 \mathrm{mM}$ sodium phosphate buffer $(\mathrm{pH}$ 6.5) containing sucrose $(0.302 \mathrm{M})$ and DTT $(1 \mathrm{mM})$ using an ultrasonic homogenizer (Vibra Cell, Ieda Boueki, Tokyo). The homogenate was centrifuged for $10 \mathrm{~min}$ at $1500 \mathrm{~g}$ and $4^{\circ} \mathrm{C}$, and the supernatant was further centrifuged for $1 \mathrm{~h}$ at $105000 \mathrm{~g}$ and $4^{\circ} \mathrm{C}$. The resulting precipitate was resuspended in $1 \mathrm{ml}$ of $40 \mathrm{mM}$ sodium phosphate buffer $(\mathrm{pH} 7.5)$ containing sucrose $(0.302 \mathrm{M})$ and DTT $(1 \mathrm{mM})$ and used as the enzyme source. All assays were performed on a freshly prepared enzyme source. The protein concentrations were estimated by the method of Bradford $^{7}$ using bovine serum albumin as the reference protein.

\section{Assay of steroid $5 \alpha$-Red activity}

A series of preliminary experiments with various incubation times (30 - $120 \mathrm{~min}), \mathrm{pH}(5-7.5)$, and enzyme source amounts $(0.025-0.2 \mathrm{mg}$ protein) were carried out in order to optimize the enzyme assay conditions. The $5 \alpha$-Red activity assay evaluated the conversion of T to $5 \alpha$-DHT and $3 \alpha, 5 \alpha$-diol. The standard incubation conditions were as follows. The incubation medium contained $20 \mu \mathrm{l}$ of $34 \mathrm{mM}$ NADPH (final concentration; $0.84 \mathrm{mM}$ ), $20 \mu \mathrm{l}$ of $0.4 \mathrm{mM} \mathrm{T}$ (EtOH solution) (final concentration; $10 \mu \mathrm{M}$ ) as the substrate, and the enzyme source $(0.1 \mathrm{mg}$ protein) was made up to a $0.8 \mathrm{ml}$ total volume with $40 \mathrm{mM}$ sodium phosphate buffer ( $\mathrm{pH}$ 7.0) containing sucrose $(0.302 \mathrm{M})$ and DTT $(1 \mathrm{mM})$. The mixture was incubated at $37^{\circ} \mathrm{C}$ for $60 \mathrm{~min}$, and the reaction was stopped by the addition of $\mathrm{MeCN}(1.5 \mathrm{ml})$ and ice cooling. The sample was diluted with $\mathrm{H}_{2} \mathrm{O}(4 \mathrm{ml})$ and applied on an Oasis HLB cartridge. After washing with $\mathrm{H}_{2} \mathrm{O}(2 \mathrm{ml})$ and $40 \% \mathrm{MeOH}(2 \mathrm{ml})$, the desired steroids were eluted with AcOEt $(1 \mathrm{ml})$ and then evaporated under a $\mathrm{N}_{2}$ gas stream. The residue was dissolved in $\mathrm{MeOH}(30 \mu \mathrm{l})$ and $10 \mu \mathrm{l}$ of which was subjected to LC/APCIMS [mobile phase, $\mathrm{MeOH}-\mathrm{H}_{2} \mathrm{O}(2: 1)$; monitoring ion, $\mathrm{m} / z, 273.1$ (5 $\alpha$-DHT) and 257.1 ( $3 \alpha, 5 \alpha$-diol); The other conditions were as already described]. The amounts of the products were calculated using the absolute calibration curve method.

\section{Calibration curves}

$5 \alpha$-DHT $(5,10,20,30,40 \mathrm{ng}$ in $40 \mu \mathrm{lof} \mathrm{EtOH})$ and $3 \alpha, 5 \alpha-$ $\operatorname{diol}(2,5,10,20,30,40 \mathrm{ng}$ in $40 \mu \mathrm{l}$ of $\mathrm{EtOH})$ were added to the standard incubation medium without NADPH (blank incubation medium), and the resulting solution was pretreated and analyzed by LC/APCI-MS as already described. The calibration curves were constructed by plotting the peak areas of the steroids $(y)$ versus the amount of the steroids (ng/tube) $(x)$.
Recoveries of $5 \alpha$-DHT and $3 \alpha, 5 \alpha$-diol from incubation medium

The first set of blank incubation media spiked with $5 \alpha$-DHT (5, $20 \mathrm{ng} /$ tube) and $3 \alpha, 5 \alpha$-diol $(2,10 \mathrm{ng} /$ tube $)$, and the second set of the blank incubation media (without $5 \alpha$-DHT and $3 \alpha, 5 \alpha-$ diol) were pretreated as already described, and then the same amount of $5 \alpha$-DHT and $3 \alpha, 5 \alpha$-diol were added to the second set. Both sets were prepared in duplicate, and subjected to the LC/APCI-MS analysis. The peak areas obtained from the first set and the second set were defined as $\mathrm{A}$ and $\mathrm{B}$, respectively. The recovery rates were calculated as $(\mathrm{A} / \mathrm{B}) \times 100$.

\section{Accuracy and reproducibility}

$5 \alpha$-DHT $(5,10,30,40 \mathrm{ng} /$ tube $)$ and $3 \alpha, 5 \alpha$-diol $(2,5,30,40$ ng/tube) were added to the blank incubation medium $(n=5)$, and after pretreatment, the obtained sample was subjected to the LC/APCI-MS analysis.

\section{Kinetic and inhibitory studies of $5 \alpha$-Red}

Varying concentrations of $\mathrm{T}$ (final concentration: $0.25,0.5$, $1.25,2.5,5,10 \mu \mathrm{M})$ were incubated with the freshly prepared rat prostatic enzyme source $(0.1 \mathrm{mg}$ protein), and the formed $5 \alpha$-DHT and $3 \alpha, 5 \alpha$-diol were determined as already described. The Michaelis constant $\left(K_{\mathrm{m}}\right)$ and maximum velocity $\left(V_{\max }\right)$ were calculated from the Lineweaver-Burk plots of $1 / v(\mathrm{nmol} / \mathrm{min} / \mathrm{mg}$ protein of sum of $5 \alpha$-DHT and $3 \alpha, 5 \alpha$-diol) versus $1 /[\mathrm{S}]$ ( $\mu \mathrm{M}$ of T). Five different enzyme sources were used for this calculation.

Fifty percent of the inhibitory concentration $\left(\mathrm{IC}_{50}\right)$ of Finasteride $^{\circledR}$ was measured with the inhibitor (final concentration: $0,10,50,100,200,400,500,1000 \mathrm{nM}$ ), T (final concentration: $20 \mu \mathrm{M}$ ) and NADPH (final concentration: 1.68 $\mathrm{mM}$ ). The medium was incubated with the freshly prepared rat prostatic enzyme source $(0.2 \mathrm{mg}$ protein) for $60 \mathrm{~min}$ at $\mathrm{pH} 5.5$, and the formed $5 \alpha$-DHT and $3 \alpha, 5 \alpha$-diol were determined as already described. The mean of the two experiments using one prostatic enzyme source was used for the calculation of the $\mathrm{IC}_{50}$.

\section{Results and Discussion}

\section{LC/APCI-MS}

First of all, authentic T (substrate), $5 \alpha$-DHT, $3 \alpha, 5 \alpha$-diol (products) and other related androgens ( $5 \beta$-DHT, $3 \alpha, 5 \beta$-diol, androsterone and etiocholanolone), which may be enzymatically formed and/or exist in the enzyme source as endogenous androgens, were separated using LC/APCI-MS in the positiveion mode. Recently, a monolithic column ${ }^{8}$ has been widely used for the high throughput HPLC analysis. We used Chromolith Performance RP-18e for the separation of the above described compounds. The $k^{\prime}$ values and ions of base peaks were listed in Table 1. Because the ions of base peaks provide the highest detection sensitivity, these ions were selected as the monitoring ions for SIM. When the mobile phase of $\mathrm{MeOH}-\mathrm{H}_{2} \mathrm{O}$ (2:1) and SIM were used, the separation of $3 \alpha, 5 \alpha$-diol ( $k^{\prime} 2.19$, $m / z$ 257.1) and $3 \alpha, 5 \beta$-diol $\left(k^{\prime} 2.27, m / z, 257.1\right)$ could not been obtained although the separation of other related steroids was obtained. But the formation of $5 \beta$-DHT, $3 \alpha, 5 \beta$-diol and etiocholanolone has not been observed in the incubation medium and the blank incubation medium, which means the $5 \beta$ steroids were not enzymatically or non-enzymatically produced in these media as described below. These data are also confirmed by using the conventional column [J'sphere ODSH80 (YMC, Kyoto); $4 \mu \mathrm{m}, 150 \times 4.6 \mathrm{~mm}$; Table 1] and we used Chromolith Performance RP-18e and $\mathrm{MeOH}-\mathrm{H}_{2} \mathrm{O}$ (2:1) as a column and mobile phase, respectively, for the separation of the 
Table 1 Separation of androgens

\begin{tabular}{lccc}
\hline & & \multicolumn{2}{c}{$k^{\prime}$} \\
\cline { 3 - 4 } \multicolumn{1}{c}{ Compound } & Base ion $(m / z)$ & $\begin{array}{c}\text { Chromolith } \\
\text { Performance } \\
\text { RP-18e }\end{array}$ & $\begin{array}{c}\text { J'sphere } \\
\text { ODS-H80 }\end{array}$ \\
\cline { 3 - 4 } \cline { 3 - 4 } & & $2: 1^{\mathrm{c}}$ & $7: 3^{\mathrm{c}}$ \\
\hline $\mathrm{T}$ & $289.1[\mathrm{M}+\mathrm{H}]^{+}$ & 1.05 & 2.54 \\
$5 \alpha$-DHT & $273.1\left[\mathrm{M}+\mathrm{H}-\mathrm{H}_{2} \mathrm{O}\right]^{+}$ & 1.77 & 4.38 \\
$5 \beta$-DHT & $273.1\left[\mathrm{M}+\mathrm{H}-\mathrm{H}_{2} \mathrm{O}\right]^{+}$ & 1.95 & 4.99 \\
$3 \alpha, 5 \alpha$-Diol & $257.1\left[\mathrm{M}+\mathrm{H}-2 \mathrm{H}_{2} \mathrm{O}\right]^{+}$ & 2.19 & 5.52 \\
$3 \alpha, 5 \beta$-Diol & $257.1\left[\mathrm{M}+\mathrm{H}-2 \mathrm{H}_{2} \mathrm{O}\right]^{+}$ & 2.27 & 5.70 \\
Androsterone & $273.1\left[\mathrm{M}+\mathrm{H}-\mathrm{H}_{2} \mathrm{O}\right]^{+}$ & 2.44 & 6.25 \\
Etiocholanolone & $273.1\left[\mathrm{M}+\mathrm{H}-\mathrm{H}_{2} \mathrm{O}\right]^{+}$ & 2.25 & 5.80 \\
\hline$R$ s of $5 \alpha$-DHT & & 1.1 & 2.5 \\
\multicolumn{1}{c}{ and $5 \beta$-DHT } & & & \\
\hline
\end{tabular}

a. $t_{0} 1.50 \mathrm{~min}\left(\mathrm{NaNO}_{3} ; 220 \mathrm{~nm}\right)$.

b. $t_{0} 1.38 \mathrm{~min}\left(\mathrm{NaNO}_{3} ; 220 \mathrm{~nm}\right)$.

c. $\mathrm{MeOH}-\mathrm{H}_{2} \mathrm{O}, 1.0 \mathrm{ml} / \mathrm{min}, 40^{\circ} \mathrm{C}$.

substrate and the products. The limits of detection of $5 \alpha$-DHT and $3 \alpha, 5 \alpha$-diol were $1.6 \mathrm{ng}$ and $600 \mathrm{pg}$ ( signal $/$ noise $=5$ ), respectively.

Determination of enzymatically formed $5 \alpha$-DHT and $3 \alpha, 5 \alpha$-diol $\mathrm{T}$ was incubated with the enzyme source and NADPH, and after the pretreatment, the extracts were analyzed using LC/APCI-MS in the full scan mode $(m / z, 250$ - 300). The peaks corresponding to $5 \alpha$-DHT and $3 \alpha, 5 \alpha$-diol appeared, and these were identified by comparison with authentic samples based on their chromatographic behavior obtained using two different columns (Chromolith Performance RP-18e, J'sphere ODS-H80) and the mass spectra. No other peak originating from the enzyme reaction and an endogenous steroid in the rat prostate, such as the $5 \beta$-reduced steroid, was observed. It is reported that $5 \beta$-reductase exists in the cytosol fraction of liver. 9 Therefore, the sum of $5 \alpha$-DHT and $3 \alpha, 5 \alpha$-diol was calculated as the amount of products in the following kinetics studies. Typical mass fragmentograms of $5 \alpha$-DHT $(\mathrm{m} / z, 273.1)$ and $3 \alpha, 5 \alpha$-diol $(\mathrm{m} / \mathrm{z}, 257.1)$ in the extracts from the standard incubation mixture and from the incubation mixture with the heat-deactivated enzyme are shown in Fig. 2.

Although the calibration curves should be drawn with the internal standards (ISs), which should be the stable isotope labeled analytes, these ISs corresponding to $5 \alpha$-DHT and $3 \alpha, 5 \alpha$-diol were neither commercially available nor easy to synthesize. We try to use $\left[{ }^{2} \mathrm{H}_{3}\right]-5 \alpha$-DHT as the IS, but satisfactory calibration curve for $3 \alpha, 5 \alpha$-diol has not been obtained. Therefore, we attempted to use the absolute calibration curve method for the determination of the products. In order to assess the linearity, a blank incubation medium spiked with graduated amounts of $5 \alpha$-DHT and $3 \alpha, 5 \alpha$-diol were analyzed by LC/APCI-MS, and the regression lines were constructed by plotting the peak areas of the steroids (y) versus the amount of the steroids (ng/tube) $(x)$. Both lines constructed using $5 \alpha$-DHT and $3 \alpha, 5 \alpha$-diol showed good linearities $\{Y=$ $0.990( \pm 0.236) X-0.358( \pm 1.68), \quad Y=3.59( \pm 0.67) X+$ 2.71( \pm 4.74$)$; mean \pm S.D., respectively, slope and intercept $(\times$ $\left.10^{5}\right), n=5$ (inter-day assay) $\}$ with a correlation coefficient $\left(r^{2}\right)$ of greater than $>0.99\{0.997 \pm 0.003$ and $0.998 \pm 0.001$ (mean \pm S.D.), respectively $\}$ within the range of $5-40 \mathrm{ng} /$ tube and 2 $40 \mathrm{ng} /$ tube, respectively, and nearly passed through the origin. (a)

(b)

(c)

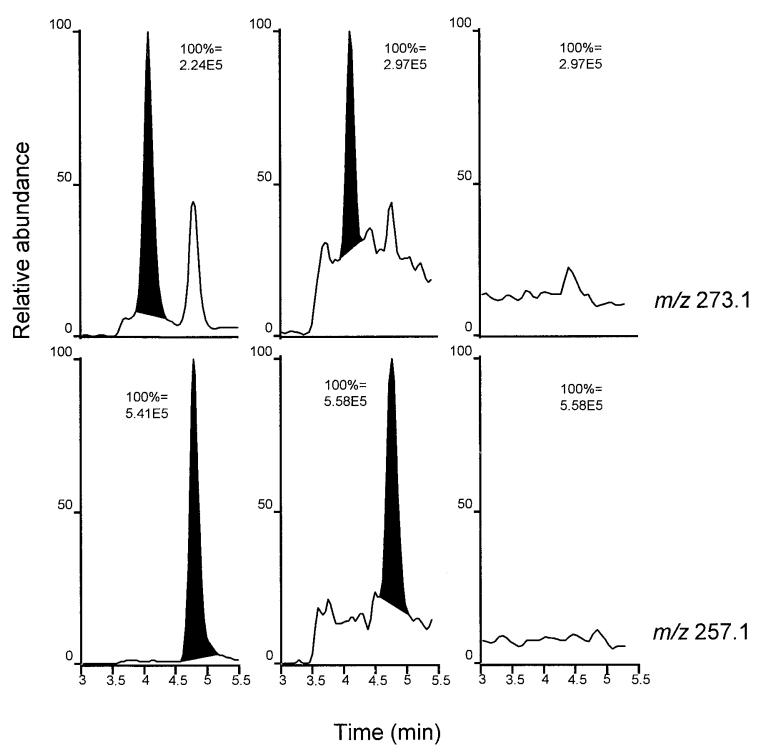

Fig. 2 Typical mass fragmentograms of $5 \alpha$-DHT and $3 \alpha, 5 \alpha$-diol. (a) Authentic samples (20 ng/tube), (b) extracts from incubation mixture and (c) extracts from incubation mixture with deactivated enzyme. SIM: $5 \alpha$-DHT ( $m / z, 273.1), 3 \alpha, 5 \alpha$-diol $(m / z, 257.1)$.

However, the slopes varied among the inter-day assay, so we used a newly prepared calibration curve for each assay.

The relative standard deviation (R.S.D.) of the calculated amounts of $5 \alpha$-DHT and $3 \alpha, 5 \alpha$-diol spiked in the blank incubation medium were lower than $15 \%$ and $10 \%$, respectively. Although the reproducibility of the $5 \alpha$-DHT determination near the quantification limit (5 ng/tube) was somewhat low, the accuracy of the assay for $5 \alpha$-DHT and $3 \alpha, 5 \alpha$-diol were satisfactory $(94.0-110 \%$ and $98.0-109$, respectively)(Table 2 ).

The absolute recovery rates from the blank incubation medium are as follows (mean, $n=2)$ : $5 \alpha$-DHT $(5 \mathrm{ng} /$ tube,

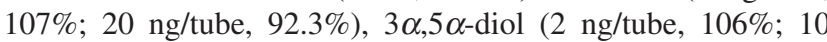
ng/tube, $96.0 \%$ )

\section{Kinetic and inhibitory studies of $5 \alpha$-Red}

In order to estimate the proposed method for the assay of the $5 \alpha$-Red activity, $K_{\mathrm{m}}$ and $V_{\max }$ for $\mathrm{T}$, and the $\mathrm{IC}_{50}$ of Finasteride ${ }^{\circledR}$ were determined. We used the rat prostatic enzyme source which contained two isoenzymes. ${ }^{6}$ The Lineweaver-Burk plot, which was constructed by plotting $1 / \mathrm{v}$ versus $1 /[\mathrm{S}]$, showed a good linearity. The $K_{\mathrm{m}}$ and $V_{\max }$ values obtained from five different rat prostatic $5 \alpha$-Reds were $0.78 \pm 0.30 \mu \mathrm{M}$ and $15.3 \pm$ $4.7 \mathrm{pmol} / \mathrm{min} / \mathrm{mg}$ protein (mean \pm S.D., $n=5$ ), respectively. The obtained $K_{\mathrm{m}}$ value is compatible with the magnitude of the reported one $(2.4 \pm 1.2 \mu \mathrm{M}, n=8) .{ }^{10}$

The $\mathrm{IC}_{50}$ value of Finasteride ${ }^{\circledR}$ was measured using twice the amounts of the substrate, enzyme source and co-factor which were used in the usual enzyme activity experiment, because its inhibition gave lower amounts of $5 \alpha$-DHT and $3 \alpha, 5 \alpha$-diol than those obtained from the usual assay. The $\mathrm{pH}$ of the incubation medium was set at 5.5, in which Finasteride ${ }^{\circledR}$ inhibited the $5 \alpha \mathrm{R} 2$ activity. ${ }^{6}$ The obtained $\mathrm{IC}_{50}$ (Fig. 3; $237 \mathrm{nM}$ ) value is compatible with the magnitude of the reported one $(470 \mathrm{nM}) .{ }^{11}$

The described LC/APCI-MS method for the determination of the rat prostatic $5 \alpha$-Red activity depends upon the sum of the 
Table 2 Precision and accuracy of the method

\begin{tabular}{|c|c|c|c|c|c|c|c|}
\hline \multicolumn{2}{|c|}{$5 \alpha$-DHT (ng/tube) } & \multirow{2}{*}{ R.S.D., \% } & \multirow{2}{*}{ Accuracy, $\%$} & \multicolumn{2}{|c|}{$3 \alpha, 5 \alpha$-Diol (ng/tube) } & \multirow{2}{*}{ R.S.D., \% } & \multirow{2}{*}{ Accuracy, $\%$} \\
\hline Added & Found $^{\mathrm{a}}$ & & & Added & Found $^{\mathrm{a}}$ & & \\
\hline 5 & $5.5 \pm 0.8$ & 14.5 & 110 & 2 & $2.1 \pm 0.2$ & 9.5 & 105 \\
\hline 10 & $9.4 \pm 1.4$ & 14.9 & 94.0 & 5 & $4.9 \pm 0.2$ & 4.1 & 98.0 \\
\hline 30 & $29.0 \pm 0.9$ & 3.1 & 96.7 & 30 & $32.7 \pm 1.7$ & 5.2 & 109 \\
\hline 40 & $40.1 \pm 4.0$ & 10.0 & 100 & 40 & $40.0 \pm 3.9$ & 9.8 & 100 \\
\hline
\end{tabular}

a. Mean \pm S.D., $n=5$.

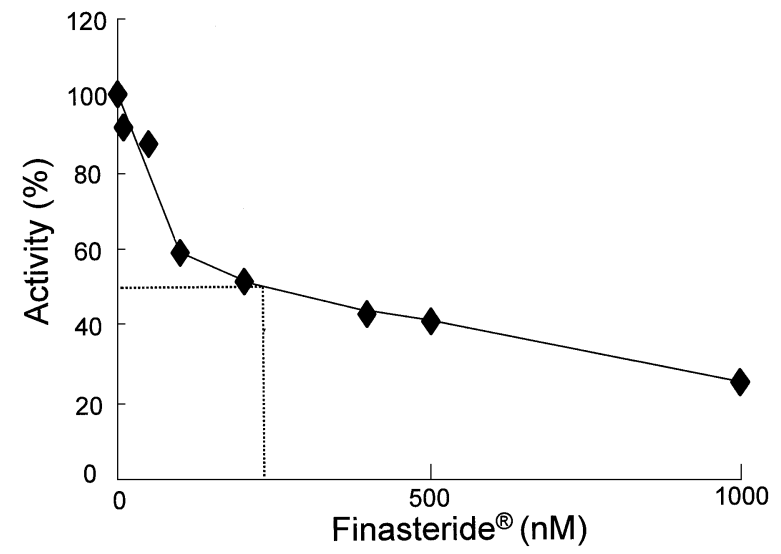

Fig. 3 Inhibitory experiment using Finasteride ${ }^{\circledR}$.

formed products from $\mathrm{T}$ using the absolute calibration curve method. The method does not require any radiolabeled compound, therefore, it is convenient for the enzyme experiments of the $5 \alpha$-Red activity or the development of its inhibitor.

\section{Acknowledgements}

The study was supported by a Grant-in-Aid for Scientific
Research from the Japan Society for the Promotion of Science. Our thanks are also due to Dr. S. Honma (Teikoku Hormone Medical Research) for supplying Finasteride ${ }^{\circledR}$ and $\left[{ }^{2} \mathrm{H}_{3}\right]-5 \alpha-$ DHT.

\section{References}

1. S. Honma, K. Minato, K. Mitamura, and K. Shimada, Horm. Front. Gynecol., 2001, 8, 115.

2. D. W. Russell and J. D. Wilson, Ann. Rev. Biochem., 1994, 63, 25.

3. G. Bartsch, R. S. Rittmaster, and H. Klocker, Eur. Urol., 2000, 37, 367.

4. J.-P. Raynaud, H. Cousse, and P.-M. Martin, J. Steroid Biochem. Mol. Biol., 2002, 82, 233.

5. K. Pratis, L. O’Donnell, G. T. Ooi, R. I. McLachlan, and D. M. Robertson, J. Steroid Biochem. Mol. Biol., 2000, 75, 75.

6. P. N. Span, Th. J. Benraad, C. G. J. Sweep, and A. G. H. Smals, J. Steroid Biochem. Mol. Biol., 1996, 57, 95.

7. M. M. Bradford, Anal. Biochem., 1976, 72, 248.

8. N. Tanaka, H. Kobayashi, K. Nakanishi, H. Minakuchi, and N. Ishizuka, Anal. Chem., 2001, 73, 421A.

9. A. Okuda and K. Okuda, J. Biol. Chem., 1984, 259, 7519.

10. T. Liang, M. A. Cascieri, A. H. Cheung, G. F. Reynolds, and G. H. Rasmusson, Endocrinology, 1985, 117, 571.

11. D. Giudici, G. Briatico, C. Cominato, T. Zaccheo, C. Iehle, M. Nesi, A. Panzeri, and E. di Salle, J. Steroid Biochem. Mol. Biol., 1996, 58, 299. 